\title{
Inheritance of Ehlers-Danlos type IV syndrome
}

\author{
F. M. POPE ${ }^{1}$, GEORGE R. MARTIN AND VICTOR A. MCKUSICK
}

From Department of Medicine, St. Nicholas Hospital, Tewson Road, Plumstead; and the Brook Hospital, Shooters Hill Road, London; Laboratory of Developmental Biology and Anomalies, National Institute of Dental Research, Bethesda, Md; and Department of Medicine, Johns Hopkins Hospital, Baltimore, Md, U.S.A.

SUMMARY The Ehlers-Danlos type IV syndrome is a severe disease with premature death fron⿳亠乛了 catastrophic tearing of large arteries and a tendency to intestinal rupture. These patients lack the genetically distinct type III collagen. Here evidence is presented that obligate heterozygotes have lowered levels of type III collagen in their skin and that their cultured fibroblasts produce less thaio normal amounts of this protein. The inheritance is autosomal recessive.

The Ehlers-Danlos syndrome (EDS) is an inherited defect of connective tissue, which combines hyperextensible fragile skin and loose jointedness with a bruising and bleeding tendency. Though earlier authors(Tschernogobow, 1892; Ehlers, 1901; Danlos, 1908) considered it a homogeneous disorder, 7 types are now recognized (McKusick, 1972) which vary in severity, in inheritance, and in the underlying molecular defects. Johnson and Falls (1949) first described autosomal dominant inheritance, though McKusick (1959) suspected that the disorder was heterogeneous. Barabas (1967) described 3 autosomal dominant varieties and Beighton et al. (1969) 5, one of which was inherited as a sex-linked recessive character. More recently 2 autosomal recessive variants have been added (Pinnell et al., 1972; Lichtenstein et al., 1973). Specific biochemical defects have been identified in EDS types V, VI, and VII. Type V only affects males and is inherited as a sex-linked recessive trait. Cultured fibroblasts from such patients are deficient in lysyl oxidase (Di Ferrante et al., 1975). Type VI combines specific clinical features such as loose jointedness, scoliosis, and retinal detachment, with type I collagen which is low in hydroxylysine (Pinnell et al., 1972). Type VII shows extreme joint laxity and short stature with the persistence of precursor forms of type I collagen (procollagen) in tissues. Both defects probably interfere with normal crosslinking of type I collagen, the major structural protein of skin, tendon, and several other tissues. EDS types I to III show autosomal

\footnotetext{
1 Present address: Division of Cell Pathology, Clinical Research Centre, Northwick Park Hospital, Harrow, Middx.

Received for publication 10 December 1976.
}

dominant inheritance, possibly with amino aci substitutions in type I collagen. Such defects as yet await demonstration.

Patients with EDS IV are readily distinguished from those with other forms of the disease. It is am especially grave disorder since premature death front major arterial tears and other severe complications such as intestinal rupture and haematomas, are commonplace. Unique clinical features include $\stackrel{\mathbb{P}}{\mathbb{2}}$ characteristic facies, unusually thin but inextensibl $\overrightarrow{\vec{E}}$ skin, and a tendency towards keloid scarring after wounding (Fig. 1). We have studied tissues from such patients; all lack type III collagen (Pope $e t$ al ${ }_{i \rightarrow}$. 1975). Moreover, cultured skin fibroblasts from these patients produce only type I collagen, in contrast t normal control cells which synthesise both types and III. The extreme fragility of skin, blood vessels. intestines, and other organs in the absence of type III collagen implies an essential structural role for it.

Here we report on levels of type III collagen io skin samples and type III collagen synthesis by skip fibroblasts in various relatives of 3 affected patients? The pedigree patterns of such biochemical studiess allow us to deduce the genetics of this disorder.

\section{Subjects and methods}

We have previously reported on 5 individuals wit EDS type IV (Pope et al., 1975). Here we describe more detailed family studies on 3 of them. In onథ family samples were available over 3 generations and in the others from 2 generations. Tissue was obtained from the skin of the right forearm by standard proo cedures, and a portion was donated to the Americ $\$$ Type Culture Collection, Rockville, Md., where ce 
strains were obtained. Chemical studies were carried out on other portions which were stored at $-20^{\circ} \mathrm{C}$ until used. Family data are shown in Fig. 2.

\section{PEDIGREE 1}

The propositus died aged 17 years after spontaneous rupture of the aorta. He had bruised and bled easily since childhood. His sibs included a completely normal brother and 2 sisters with minimal loose jointedness.

PEDIGREE 2

The propositus aged 27 had suffered a variety of vascular ruptures including both femoral arteries, a
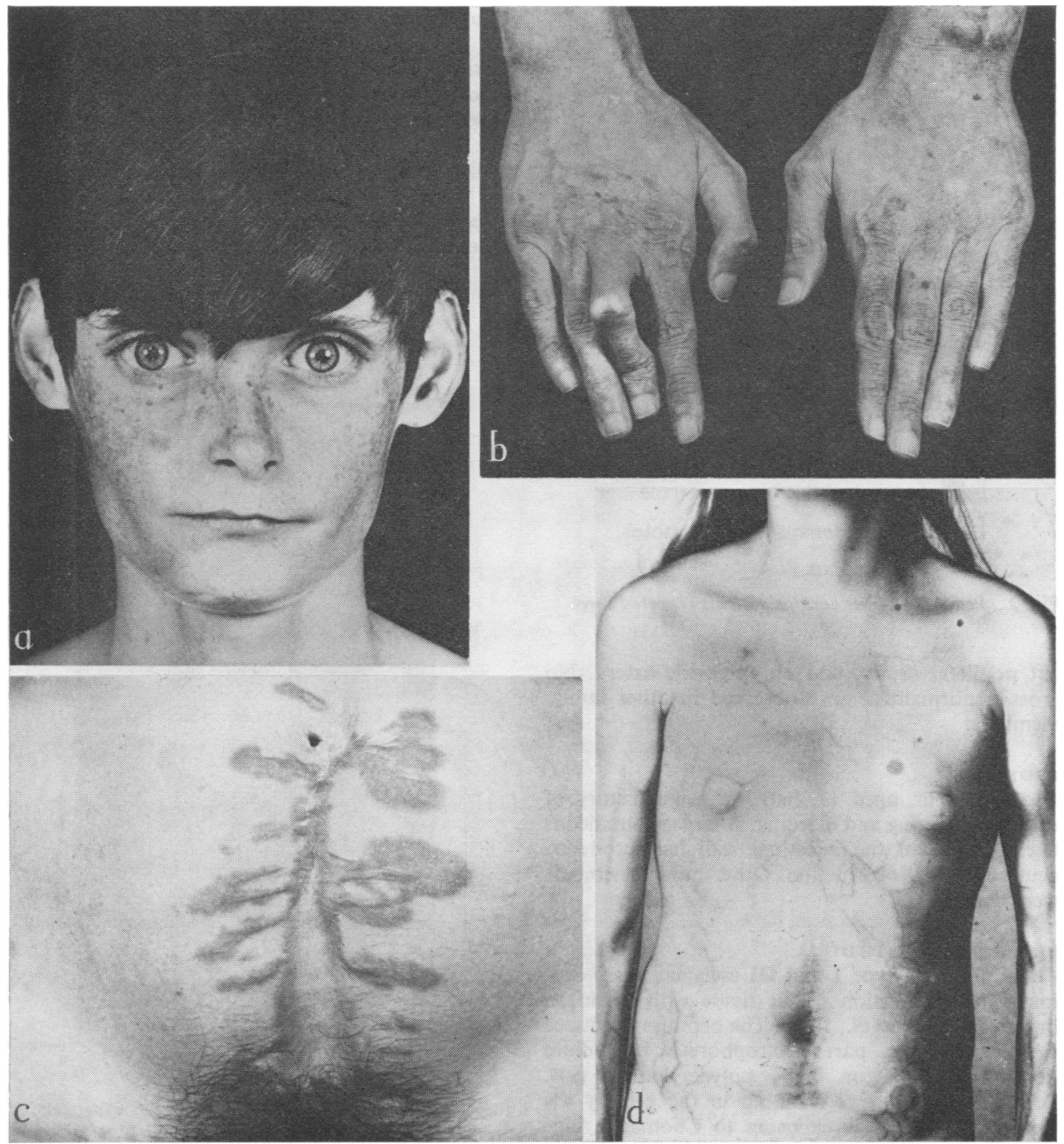

Fig. 1 (a) Characteristic facies of an EDS IV patient; (b) the hands are prematurely aged (acrogeria); (c) keloids are common; $(d)$ the skin is exceptionally thin with a prominent venous pattern. Note splenectomy and laparotomy scars. 

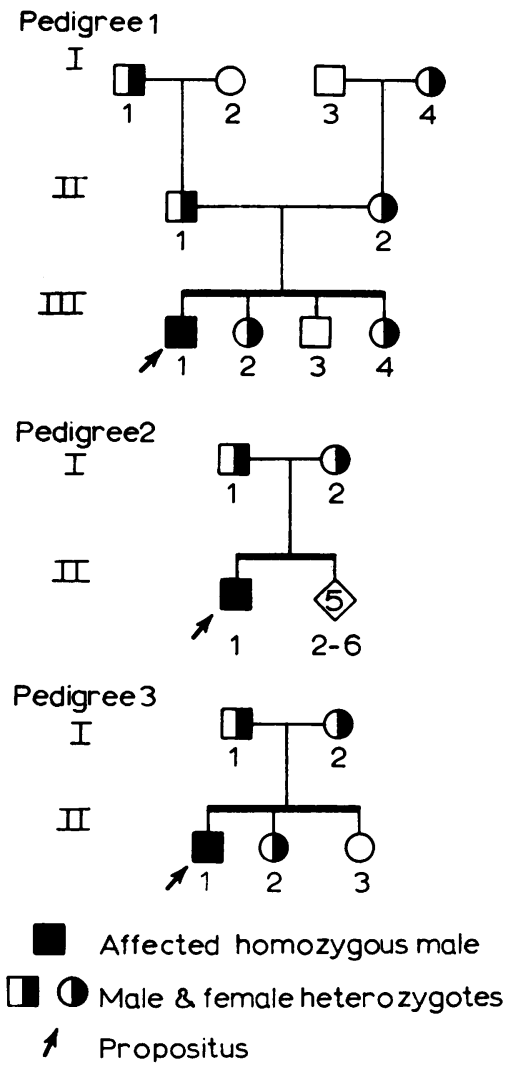

Fig. 2 Pedigrees of the various patients reported here.

left popliteal artery, and an epigastric artery. No gross abnormalities were observed in other family members.

\section{PEDIGREE 3}

The proposita, aged 17 , had the usual history of excessive bruising and bleeding. A large spontaneous haemorrhage of the intestinal wall had produced acute intestinal obstruction. Other family members were normal.

\section{BIOCHEMICAL STUDIES}

The amount of type I and III collagens were estimated after digestion of the tissue with cyanogen bromide (Miller et al., 1971). The peptides produced were resolved in part electrophoresis in sodium dodecyl sulphate on $7.5 \%$ polyacrylamide gels. Peptidyl material was localized in the gels by the uptake of stain after exposure to Coomassie blue and subsequent removal of unbound dye (Furthmayr and Timpl, 1971). Authentic samples of type I and III collagen were prepared by standard methods

from fetal skin (Chung and Miller, 1974; Epstein, 1974; Trelstad et al., 1974). The patterns of peptides produced from skin by digestion with cyanogen : bromide were compared with the peptides produced $\overline{\vec{s}}$ from these standards. In addition, we used authentico $\alpha \mathrm{I}(\mathrm{III})-\mathrm{CB} 8$ (the kind of gift of Dr Ervin Epstein) as a standard.

\section{FIBROBLAST STUDIES}

Cell strains were obtained from the American Type $e^{\infty}$ Culture Collection of mutant Human Strains. Con- $\vec{O}$ fluent cultures of these cells were exposed to media containing $20 \mu \mathrm{Ci}$ each of ${ }^{14} \mathrm{C}$-glycine and ${ }^{14} \mathrm{C}$-pro- $\stackrel{\omega}{\circ}$ line. The medium lacked carrier lysine, glycine, and $\overline{3}$ proline and was supplemented with ascorbic acido and $\beta$-aminopropionitrile as previously described. $\overrightarrow{+}$ After a 24-hour labelling period, the medium was ${ }^{c}$ removed from each culture and collagenous protein

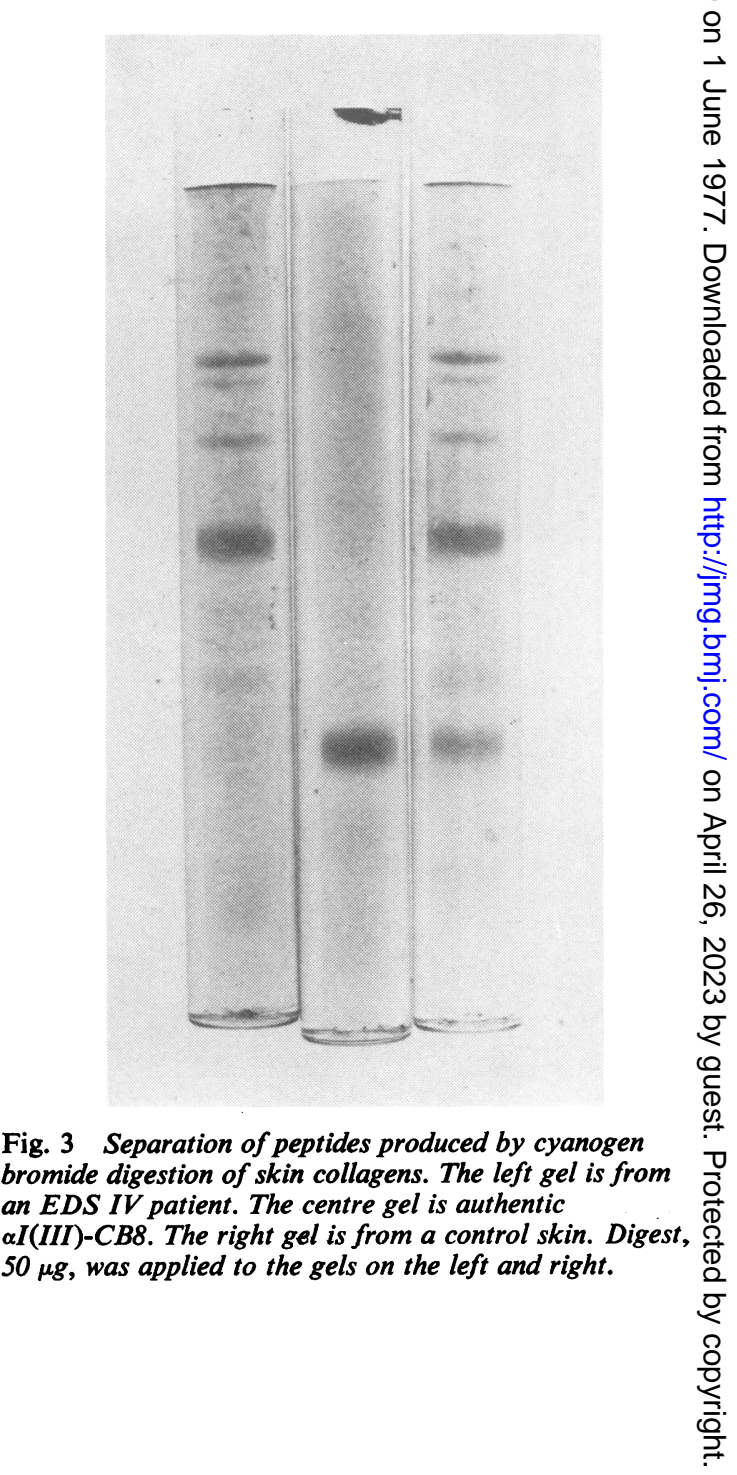


precipitated by the addition of $\left(\mathrm{NH}_{4}\right)_{2} \mathrm{SO}_{4}$ to a $20 \%$ saturation (Church et al., 1973). The precipitated materials were dissolved in $0.05 \mathrm{M}$ Tris- $\mathrm{HCl}, \mathrm{pH} 7.4$ and type I procollagen was resolved from type III procollagen by chromatography on DEAE-cellulose (Church et al., 1974; Smith et al., 1972).

\section{Results}

After digestion with $\mathrm{CNBr}$ at least on peptide produced from type III collagen, $\alpha$ I(III)-CB8 can be readily resolved from peptides produced from type I collagen. In our previous study, we showed that this peptide was not detectable in digests of skin and the other tissues from 5 ED-IV patients (Pope et al., 1975). Similar results were obtained here. Surprisingly, when the peptides produced from the skin of certain apparently normal family members were examined at normal sample loads, the type III collagen specific peptide was not seen (Fig. 3). However, when the amount of protein applied to the gel was increased, we could detect $\alpha$ I(III)-CB8 (Fig. 4). In general, twice to three times as much digest was required to obtain levels of $\alpha$ I(III)-CB8 comparable to those obtained from normal controls. Tissue from still other family members produced normal levels of I(III)-CB8 while none of this peptide was observed at any sample load from digests of EDS IV tissue.

Most of the collagenous protein produced in culture by cells obtained from skin biopsies accumulates in the culture media as procollagens (Church

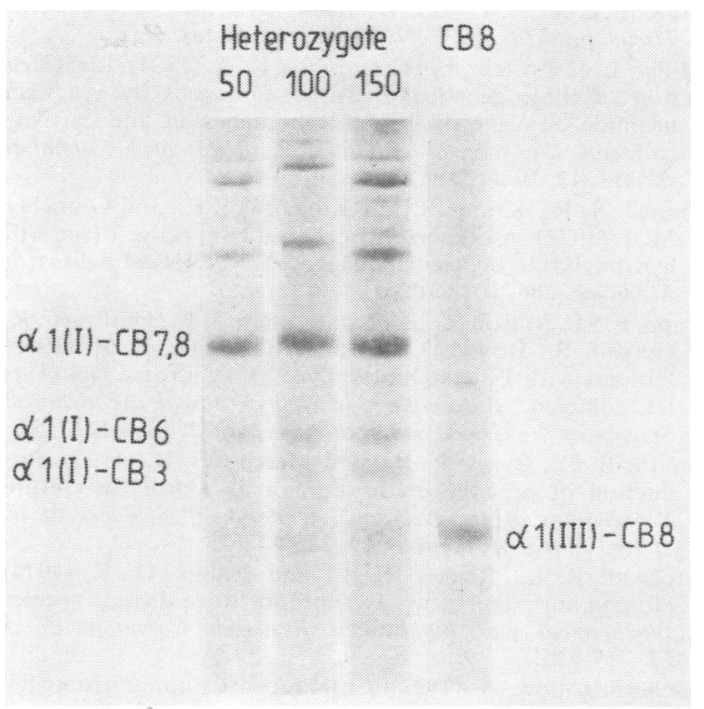

Fig. 4 Demonstration of an $\alpha I(I I I)$ derived peptide in digested heterozygote skin with increasing sample sizes. et al., 1974; Smith et al., 1972; Layman et al., 1971; Lichtenstein et al., 1975). While EDS IV cell strains produce only type I procollagen, all others so far examined produce both type I and type III procollagens (Church et al., 1974; Lichtenstein et al., 1975). We observed similar results here (Fig. 5).

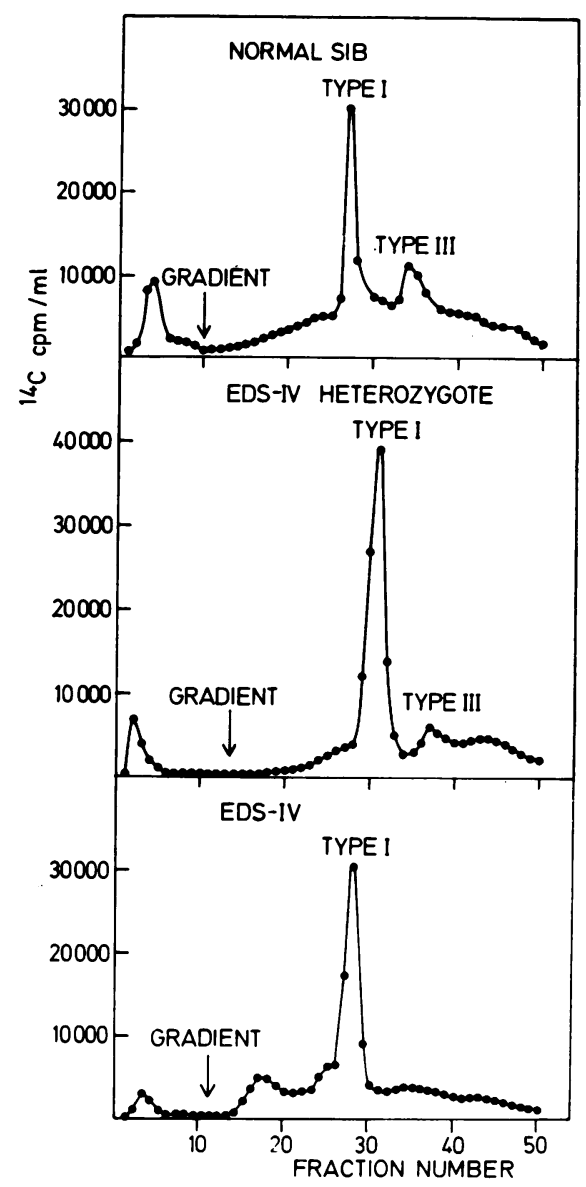

Fig. 5 The measurement of type I and III procollagen synthesis by cultured fibroblasts. The labelled procollagens secreted by the cells were resolved by DEAE-cellulose chromatography.

However, cells from heterozygous individuals whose skin contained less type III collagen also produced less type III collagen in culture. In general, this represented no more than half the normal amount of type III relative to type I procollagen. The overall level of collagen synthesized was similar in all these cell lines. 


\section{Discussion}

While type I collagen is the most abundant protein in the body, there are other genetically and chemically distinct collagens, including type II or cartilage collagen and type IV or basement membrane collagen. Type III collagen is found in many of the same tissues as type I collagen but is located in anatomically distinct fibres (Gay et al., 1975).

The tissue weakness observed in patients with the EDS IV syndrome is caused by a lack of type III collagen. Some apparently normal relatives of 3 patients with this disorder have lower than normal levels of type III collagen in their skin. Their fibroblasts make less type III collagen relative to type I collagen than normal cell strains. Still other family members have normal cutaneous levels of type III collagen and their cell strains make a normal proportion of type I and III collagens (Fig. 5). We interpret these results to mean that in these families EDA IV is transmitted as an autosomal recessive trait. Obligate heterozygotes are clinically undistinguished but do not make or have a normal amount of type III collagen. Earlier authors have suggested that EDS IV is transmitted as an autosomal dominant trait (Barabas, 1967; Beighton, 1970). Undoubtedly, the patients described by them are heterogeneous, some have the disorder which we have studied while others do not. Of course, it is possible that a deficiency of type III collagen could occur in other families as autosomal dominant defects. There are obvious parallels between our disorder and the thalassaemias. Both have the complete absence of an essential protein in affected individuals with intermediate levels in heterozygotes. In contrast to the thalassaemias the obligate heterozygotes of EDS IV show little or no clinical defect.

\section{References}

Barabas, A. P. (1967). Heterogeneity of the Ehlers-Danlos syndrome: description of three clinical types and a hypothesis to explain basic defect. British Medical Journal, 2, 612-613.

Beighton, P. (1970). The Ehlers-Danlos Syndrome. William Heinemann Medical Books.

Beighton, P., Price, A., Lord, J., and Dickson, E. (1969). Variants of the Ehlers-Danlos syndrome. Clinical, biochemical, haematological, and chromosomal features of 100 patients. Annals of the Rheumatic Diseases, 28, 228-242.

Chung, E., and Miller, E. J. (1974). Collagen polymorphism. Characteristics of molecules with chain composition $\alpha 1(\mathrm{III})_{3}$ in human tissues. Science, 183, 1200-1201.

Church, R. L., Tanzer, M. L., and Lapiere, C. M. (1974). Identification of two distinct species of collagen synthesised by a clonal line of calf dermatosparatic cells. Nature New Biology, 244, 188-190.

Danlos, M. (1908). Un cas de Cutis Laxa avec tumours par contusion chronique des coudes et des genoux. (Xanthome diabetique de M. M. Hallopean et Mace de Lepinay) $\mathbb{Q}$ Bulletin de la Société Française de Dermatologie et dẹ Syphiligraphie, 19, 70-72.

Di Ferrante, N., Leachman, R. D., Angelini, P., Donnel| P. V., Francis, G., and Almazan, A. (1975). Lysyl oxi dase deficiency in Ehlers-Danlos Syndrome Type V. Con은 nective Tissue Research, 3 (1), 49-53.

Ehlers, E. (1901). Cutis Laxa, Neigung zu Haemorrhagien irs? der Haut; hockerung mehrerer Artikulationem. Dermato logische Zeitschrift, 8, 173.

Epstein, E. H. (1974). $\alpha 1$ (III) 3 human skin collagen release bx̃ pepsin digestion and preponderance in fetal life. Journal of Biological Chemistry, 249, 3225-3231.

Furthmayr, H., and Timpl, R. (1971). Characterisation of $\overrightarrow{\vec{r}}$ collagen peptides by sodium dodecylsulphate polyacryla $\omega^{\omega}$ mide electrophoresis. Analytical Biochemistry, 41, 510-516.

Gay, S., Balleisin, L., Remberger, K., Fietzek, P. P., Adel mann, B. C., and Kuhn, K. (1975). Immunohistochemical evidence for presence of collagen type III in human arteriat thrombi and in leucocytes incubated with collagen in vitros Klinische Wochenschrift, 53, 899-902.

Johnson, S. A. M., and Falls, H. T. (1949). Ehlers-Danlos syndrome, a clinical and genetic study. Archives of Der? matology, 60, 82-105.

Layman, D. L., McGoodwin, E., and Martin, G. R. (1971) The nature of collagen synthesised on cultured human fibroblasts. Proceedings of the National Academy ofD Sciences of the United States of America, 68, 454-458.

Lichtenstein, J. R., Byers, P. H., Smith, B. R., and Martin, G. R. (1975). Identification of the collagenous proteins synthesised by cultured cells from human skin. Bio chemistry, 14, 1589-1594.

Lichtenstein, J. R., Martin, G. R., Kohn, L. D., Byers, P. H., and McKusick, V. A. (1973). Defect in the conversion of procollagen to collagen in a form of Ehlers-Danlos syn drome. Science, 182, 298-299.

McKusick, V. A. (1959). Hereditary disorders of connective tissue. Bulletin of New York Academy of Medicine, $35 \overrightarrow{\widehat{O}}$ 141-156.

McKusick, V. A. (1972). Heritable Disorders of Connective Tissue, pp. 339-340. C. V. Mosby, St. Louis.

Miller, E. J., Epstein, E. H., and Piez, K. A. (1971). Identifica tion of three genetically distinct collagens by cyanogen bromide cleavage of insoluble human skin and cartilage collagen. Biochemical and Biophysical Research Communio cations, 42, 1024-1029.

Pinnell, S. R., Krane, S. M., Kenzora, J. E., and Glimcher M. J. (1972). A heritable disorder of connective tissue with hydroxylysine deficient collagen. New England Journal of Medicine, 286, 1013-1020.

Pope, F. M., Martin, G. R., Lichtenstein, J. R., Penttinen, R. $\rightarrow$ Gerson, B., Rowe, D. W., and McKusick, V. A. (1975) Patients with Ehlers-Danlos Type IV syndrome lack TypeIII collagen. Proceedings of the National Academy of Science of the United States of America, 72, 1314-1317.

Smith, B. D., Byers, P. H., and Martin, G. R. (1972). Pro N duction of procollagen by human fibroblasts in culture Proceedings of the National Academy of Sciences of the United States of America, 69, 3260-3262.

Trelstad, R. L., Rizzie, K. R., and Rubin, D. F. (1974)은 Human aorta collagens: evidence for three distinct species $\mathbb{D}$ Biochemical and Biophysical Research Communications, 57, 717-725.

Tschernogobow, A. (1892). Cutis Laxa. Communication IV Moskauer dermatologische und venerologische gesell schaft. Monatshefte für praktische Dermatologie, 14, 76. 